\title{
Arbuscular cotton-associated mycorrhizal fungi in Yeola region of Maharashtra, India
}

\author{
SW Patale
}

Department of Botany, Swami Muktanand College of Science, Yeola; District Nasik 423401 India

\begin{abstract}
Mycorrhizae are a mutual symbiotic link between the plant root and a fungus that colonizes the cortical tissue of the roots during active plant growth periods. Both the host plant and the fungus have the potential to benefit. Mycorrhizae are ubiquitous throughout the world in terrestrial ecosystems. The purpose of this study is to evaluate the association of arbuscular mycorrhizal fungi in cotton crops with AM fungal population density in rhizosphere soils, investigate the qualitative composition of AM fungal species and the percentage of root colonization. The results showed that the number of AM fungal propagules collected from different locations in cotton crops ranged from 235 to 1580 spores per $100 \mathrm{~g}$ of soil. Due to the widespread nature of AM fungi, they occurred in almost all soil samples, but the number and type of spores and sporocarps varied. In total, 41 AM fungal species belonging to the genera Glomus, Acaulospora and Scutellospora were isolated. Glomus was found to be predominantly followed by Scutellospora in cotton soils in the rhizosphere. The distribution of spores, density and composition of AM fungi are observed to be influenced by environmental and physicochemical factors. The AM spore number, root colonization percentage and distribution vary depending on the seasonal fluctuations in moisture, temperature, $\mathrm{pH}$ and soil mineral nutrient status such as $\mathrm{OC}, \mathrm{P}_{2} \mathrm{O}_{5}, \mathrm{~K}_{2} \mathrm{O}, \mathrm{Zn}, \mathrm{Cu}, \mathrm{Fe}, \mathrm{Mn}$, etc. The obtained data shows that nitrogen-deficient soils had more AM fungal propagules. The soils with a high concentration of phosphorus and potassium had the least AM fungal spores. Depleted zinc, copper and manganese levels have also been positive for more fungal occurrence and distribution. The presence of high iron levels in the soil, however, encourages more AM spores and a percentage of root colonisation.
\end{abstract}

Key words: Cotton; arbuscular mycorrhizal fungi; rhizosphere; root colonization.

\section{INTRODUCTION}

Since the Paleozoic era (Taylor 1990), Mycorrhizae has been linked to vascular plants. Arbuscular mycorrhizae (AM), the most prevalent association of plant fungi, comprises about 150 species belonging to the Zygomycotina Glomales (Morton \& Bentivenga 1994; Myrold 2000; Perry et al., 1989; Schenk 1981; Simon1996). Arbuscular mycorrhizal (AM) symbiosis is an association between most terrestrial plants and a host plant class of fungi (Glomeromycota) (Schussler et al., 2001). Root colonization with AM fungi has been shown to improve the productivity of many crop plants in dry soils (Al-Karaki and Al-Raddad 1997; Al-Karaki and Clark 1998; Faber et al., 1990 and Sylvia et al., 1993). Ultimately AM fungi improve soil structure by binding soil particles together.

Cotton belongs to the family Malvaceae. It is native to the tropics and warm temperate regions. Commercial species of cotton plant are G. hirsutum (90\% of world production), G. barbadense (8\%), G. arboreum and G. herbaceum (together, 2\%). 
Nehl et al., (1996, 1998) demonstrated that mycorrhizal colonization, root browning and soil properties associated with cotton growth disorder in Australia and slow mycorrhizal arbuscular colonization in field - grown cotton due to soil environmental conditions. Pattinson et al., (1997) studied the effect of Terrazole and Terraclor fungicides and Fenamiphos nematicide on Glomus mosseae root colonization and the growth of cotton seedlings. Zak et al., (1998) studied Arbuscularmycorrhizal colonization dynamics of cotton (Gossypium hirsutum L.) growing under several production systems on the Southern High Plains of Texas. Mc Gee, et al., (1999) have reviewed the relationship between density of Glomus mosseae propagules and the initiation and spread of arbuscular mycorrhizas in cotton roots. Feng et al., (2002) have shown the uptake of nitrogen from indigenous soil pool by cotton plant inoculated with arbuscular mycorrhizal fungi. Hulugalle et al., (2004) studied soil properties, and cotton growth, yield and fiber quality in three cotton-based cropping systems. Patale and Shinde (2012b) studied effect of water stress on growth performance of Bt- cotton inoculated with AM Fungi. Patale and Shinde (2012a) described growth performance of Btcotton inoculated with AM Fungi on salinity stress. Patale and Shinde (2012c) studied influence of Glomus species and soil phosphorous on Verticillium wilt in Bt- cotton.

Cotton is cultivated in Maharashtra as a chief commercial crop, survey of literature do not show any report on association of AM Fungi with cotton in this area. The study of this association will definitely be useful to all cotton growers to increase yield and to improve fertility of soil. The use of AM fungi will also reduce soil pollution due to application of Chemical fertilizers and fungicides in cotton fields as AM fungi are ecofriendly.

\section{MATERIALS AND METHODS}

In the present study, cotton crop commonly grown, in and around Yeola viz., Saigaon (S1), Patoda (S2), Golhewadi (S3), Kotamgaon (S4), Bharam (S5), Kusur (S6), Gawandgaon (S7) and Mukhed (S8) were surveyed for arbuscular mycorrhizal (AM) fungal association.

Fresh samples of soil were taken to the laboratory. Fine roots were fixed in the formalin acetic acid alcohol solution (90:5:5) after washing thoroughly to determine the root infection. Soil samples were dried air in the shade for additional spores at laboratory temperature. Roots were autoclaved in $\mathrm{KOH}$ solution for 15 to 20 minutes (10 per cent), cleaned in distilled water and neutralized with $\mathrm{HCl}$ ( 2 per cent) and stained in lacto phenol in trypan blue (0.05 per cent). Phillips and Hayman's (1970) method measured the percentage of the root infection.

$100 \mathrm{~g}$ of air - dried soil mixture with $1000 \mathrm{ml}$ of tap water has been placed in a beaker. The mixture of the root soil has been strongly mixed with glass rod for 30 seconds. The remaining soilroot-hyphae-spore suspension was slowly poured through 240, 170, 150,100 and $72 \mu \mathrm{m}$ sieves after the soil particles and organic debris were settled. The extracts were washed off the sieves to what man filter paper. Spores, aggregates and sporocarps were picked by needle using trinocular research microscopes (Gerdemann and Nicolson, 1963). To each PVLG drop, 5 - 10 spores have been added. 
The mounting system was allowed to set for 3 - 5 minutes before a cover slip was added. The identification of isolated spores was carried out by Schenck and Perez (1990) using the key proposed.

The cotton rhizosphere soil was analyzed for the physical and chemical characteristics of soil samples such as pH, EC, OC, P, K, Zn, Cu, Fe and Mn performed using Jackson's (1973) procedure.

\section{RESULTS AND DISCUSSION}

\section{Ecology of AM fungi}

The presence of AM fungi was screened for cotton plants belonging to the Malvaceae family. Data on fungal propagules isolated from these plants ' soil samples collected from different locations are given in Table 1. Soil samples collected from eight different locations were found to be associated with AM fungus. All samples collected from the ground showed a percentage of root colonization, regardless of location (Table 1). The data indicates the number of AM fungal propagules accumulated in different crops from different locations ranging from 235 to 1580 spores per $100 \mathrm{~g}$ soil. Of all the 8 soil samples surveyed, Mukhed soils contain more AM propagules of 1580 per $100 \mathrm{~g}$ of soil; while Patoda soil samples showed less than 235 spores per $100 \mathrm{~g}$ of soil. In all, 41 AM fungal species representing three genera, namely Acaulospora, Glomus and Scutellospora, have been isolated (Table 2).Glomus representing twenty - two species, seven species of Acaulospora and twelve species of Scutellospora. Out of these twenty AM fungal species, the present soils are dominated by Glomus species followed by Scutellospora.

\section{Physico-chemical factors of the Soil}

Table 1 presents data on the physico-chemical characteristics of the rhizosphere soil samples of cotton collected from different locations in relation to the number of propagules. All the soils investigated in this study were of sandy loam type and were fertilized organically and chemically. The soils had a pH range of 8 to 8.95 . More propagules were shown in the slightly alkaline $\mathrm{pH}$ soils.

Data from the soils of the rhizosphere showed that organic carbon-deficient soils had more AM fungal propagules. Soils with a low organic carbon content of $0.22 \%$ had 1580 AM fungal propagules per $100 \mathrm{~g}$. While high organic carbon soil samples (1.23 percent) had a lower spore density of 240 per $100 \mathrm{~g}$. These soil samples were studied for their phosphorus content and it was observed that soils containing 3 to $4 \mathrm{~kg} /$ ac phosphorus had a maximum number of AM fungal spores, while soils with a lower number of AM fungal spores had high phosphorus content, i.e. 12 to $16 \mathrm{~kg}$ per acre.

High potassium levels contain the smallest amount of AM spores compared to soils with low potassium levels. It was therefore evident that low potassium levels favored more AM fungal spore association. Similarly, soils with minimum levels of copper, zinc, iron and manganese were favorable for the occurrence and distribution of more AM funguses. However, high iron levels are favorable for more AM spore occurrence. 


\section{AM fungal root colonization}

The percentage of AM cotton fungal root colonization from all selected sites is shown in table 1. It is clear from the data that the percentage of root colonization in the cotton samples collected at different locations varied. The percentage of root colonization in the Mukhed samples was found to be maximum (95\%) and minimum (63.64\%) in Patoda samples. Saigaon root samples were found to be heavily colonized with vesicles.

In this study, the population dynamics of AM fungi were determined by the collection of the remaining spores in and around Yeola from different soils of brinjal, tomato and cotton. Because of the widespread nature of AM fungi, these occurred in nearly all soil samples, but with a variation in the number and type of spores and sporocarps regardless of the location.

A total of 41 AM fungal species have been isolated from eight different soils of Glomus, Acaulospora and Scutellospora genera. Among the soil samples collected from Saigaon, there were more AM propagules followed by Mukhed soil samples, which could be due to low nutrient status and average humidity levels.

Glomus was predominantly among the 41 AM fungal species isolated from the rhizospheric soils of cotton crops, followed by Scutellospora. The results support the previous studies very strongly (Patale and Shinde 2010a, b; Patale 2016). Earlier reports also revealed the predominance of the above-mentioned AM fungal genera in plant cultivar rhizosphere soils (Gerdemann and Trappe, 1974; Hall and Abbott, 1984).

\section{Effect of soil's physico-chemical factors}

It has been observed that the distribution of spores, density and composition of AM fungi are influenced by environmental and physicochemical factors. The number of AM spores, the percentage of root colonization and the distribution are affected by the seasonal fluctuations in humidity, temperature, $\mathrm{pH}$ and soil nutrient status such as N, P, K, Zn, Fe, etc. Earlier studies in chili, sorghum, mungbean, tomato, brinjal and soybean by Bagyaraj and Sreeramulu (1982), Reddy et al., (2006), Reddy et al., (2007), Patale and Shinde (2010a, b) and Patale (2016) also showed similar trends.

In the present study, the population of mycorrhizal spores in rhizosphere soil and the percentage of mycorrhizal infection in plant roots fluctuated with changes in soil physico-chemical factors. The results coincide with the earlier results of Reddy et al., (2007) in sorghum crops.

Light textured sandy loam soil with neutral to slightly alkaline $\mathrm{pH}$, low humidity favored an extensive association of mycorrhizal roots (Sreeramulu and Bhagyaraj, 1986). The $\mathrm{pH}$ of the soil in our study ranged from 8 to 8.95 , which was slightly alkaline and had more, AM fungal propagules.

In this study, soils with low organic carbon levels such as 0.17 percent of the soil contained 1278 AM fungal propagules per $100 \mathrm{gm}$ of soil and 92 percent root colonization, but soil samples with a nitrogen content of 1.23 percent contained only 240 spores per $100 \mathrm{~g}$ of soil and 85.71 percent root colonization. It therefore clearly indicates that high nitrogen levels reduce the number of AM propagules and the percentage of root infection that is in line with the research published by Azcon- 
Aquilar and Barea (1982), Patale and Shinde (2010a, b) and Patale (2016).

The deficiency of phosphorus in semi - arid soils is the rule of the association of AM plants (Williams et al., 1974). Mosse (1981) observed that high levels of free soil phosphorus decreased mycorrhizal development, while Ojala et al., (1983) recorded a decrease in plant mycorrhizal dependency with an increase in phosphorus available in the soil. Our study also showed the same trend that samples with a higher phosphorous content $(16 \mathrm{~kg} / \mathrm{ac})$ had less AM propagules than the soil with a lower phosphorus content ( 3 to $4 \mathrm{~kg} / \mathrm{ac}$ ) with a maximum number of AM spores. AM fungi, particularly phosphorus (P), have been found to improve plant mineral nutrition. Smith and Read (1997) obtained the same results.

According to our experimental results of the soil samples, high potassium levels in the soil had less AM spores than those with low potassium levels. Our findings coincide with Barea et al., (2002), and Suresh et al., (2000)'s observations that low potassium levels favored more AM fungal associations than high potassium levels in the soil. Similar trends have been observed that low concentrations of $\mathrm{Zn}$, copper and manganese and high iron levels favor AM fungal propaganda. These comments are consistent with the previous reports (Barea et al. , 2002; Brundrett, 2002; Garg and Chandel, 2010).

In the present study, the genus Glomus has been represented by more species than the other genera, which indicates its predominance. This study gives a clear understanding of the AM fungi ecology.

Because of the widespread nature of AM fungi, these occurred in nearly all soil samples, but with a variation in the number and type of spores and sporocarps regardless of the location. The Glomus genus was represented by more species than the other genera, which showed its predominance. This study gives a clear understanding of the AM fungi ecology.

It was concluded that $\mathrm{AM}$ fungi were adapted to crop plants and the environment that manage indigenous fungal populations in agricultural practices so that the population of efficient indigenous fungi is increased.

Table.1 Number of AM fungal propagules in relation to physico-chemical factors in the rhizosphere soil samples of Cotton

\begin{tabular}{|c|r|r|r|r|r|r|r|r|}
\hline Locality & \multicolumn{1}{|c|}{ S1 } & \multicolumn{1}{c|}{ S2 } & \multicolumn{1}{c|}{ S3 } & \multicolumn{1}{c|}{ S4 } & \multicolumn{1}{c|}{ S5 } & \multicolumn{1}{c|}{ S6 } & \multicolumn{1}{c|}{ S7 } & \multicolumn{1}{c|}{ S8 } \\
\hline No. of Spores /100 g & 1278.00 & 235.00 & 424.00 & 240.00 & 442.00 & 786.00 & 1124.00 & 1580.00 \\
\hline \% Root Infection & 92.00 & 63.64 & 93.33 & 85.71 & 82.00 & 72.00 & 93.00 & 95.00 \\
\hline $\mathrm{pH}$ & 8.10 & 8.95 & 8.80 & 8.85 & 8.00 & 8.30 & 8.30 & 8.00 \\
\hline $\mathrm{EC}$ & 0.64 & 0.26 & 0.20 & 0.23 & 0.79 & 0.49 & 0.26 & 0.17 \\
\hline $\mathrm{OC} \%$ & 0.17 & 0.52 & 0.41 & 1.23 & 0.53 & 0.09 & 0.34 & 0.22 \\
\hline $\mathrm{P} 2 \mathrm{O} 5 \mathrm{Kg} / \mathrm{ac}$ & 3.00 & 12.00 & 16.00 & 14.00 & 6.00 & 3.00 & 3.00 & 4.00 \\
\hline $\mathrm{K} 2 \mathrm{O} \mathrm{Kg} / \mathrm{ac}$ & 138.00 & 362.00 & 205.00 & 224.00 & 280.00 & 138.00 & 150.00 & 100.00 \\
\hline $\mathrm{Zn} \mathrm{ppm}$ & 0.31 & 0.29 & 0.76 & 0.67 & 0.47 & 0.21 & 0.42 & 0.26 \\
\hline $\mathrm{Cu} \mathrm{ppm}$ & 0.31 & 1.75 & 1.53 & 1.76 & 5.00 & 3.00 & 4.00 & 0.40 \\
\hline $\mathrm{Fe} \mathrm{ppm}$ & 10.90 & 7.26 & 9.41 & 11.28 & 5.60 & 0.70 & 12.30 & 11.90 \\
\hline
\end{tabular}


Mn ppm

$26.80|116.65|$

$119.13 \mid 104.25$

$17.50 \quad 16.30$

21.60

17.90

Saigaon (S1), Patoda (S2), Golhewadi (S3), Kotamgaon (S4), Bharam (S5), Kusur (S6),

Gawandgaon (S7) and Mukhed (S8)

Table.2 Arbuscular mycorrhizal fungal spore distribution in the rhizosphere soils of Cotton collected from different locations

\begin{tabular}{|c|c|c|c|c|c|c|c|c|c|}
\hline Sr. No. & Name of Genus and species & $\mathrm{S} 1$ & S2 & $\mathrm{S} 3$ & S4 & S5 & S6 & S7 & S8 \\
\hline 1 & Acaulospora appendiculata & + & - & + & + & - & - & - & + \\
\hline 2 & Acaulospora delicata & + & - & + & - & - & - & - & + \\
\hline 3 & Acaulospora denticulata & + & - & + & - & - & - & + & - \\
\hline 4 & Acaulospora foveata & - & - & - & + & - & + & + & + \\
\hline 5 & Acaulospora laevis & + & - & + & - & + & - & - & + \\
\hline 6 & Acaulospora nicolsonii & - & + & - & - & + & - & + & - \\
\hline 7 & Acaulospora polonica & + & + & + & - & - & + & - & - \\
\hline 8 & Glomus albidium & + & + & + & - & - & + & + & + \\
\hline 9 & Glomus aggregatum & - & - & - & + & - & - & + & + \\
\hline 10 & Glomus boreale & - & - & - & - & + & - & + & + \\
\hline 11 & Glomus callosum & - & - & - & + & - & + & - & + \\
\hline 12 & Glomus constrictum & + & + & + & + & + & - & + & - \\
\hline 13 & Glomus convolutum & - & + & - & - & - & - & + & - \\
\hline 14 & Glomus dimorphicum & + & - & + & - & - & + & - & + \\
\hline 15 & Glomus etunicatum & + & + & - & + & - & - & + & + \\
\hline 16 & Glomus fasciculatum & + & + & + & + & - & - & + & + \\
\hline 17 & Glomus fecundisporum & + & + & + & + & + & + & + & + \\
\hline 18 & Glomus fistulosum & + & - & + & - & - & - & - & - \\
\hline 19 & Glomus formosanum & + & - & + & - & - & - & - & + \\
\hline 20 & Glomus fragilistratum & - & - & - & + & - & - & + & + \\
\hline 21 & Glomus globiferum & + & + & + & + & - & - & - & + \\
\hline 22 & Glomus heterosporum & - & - & - & + & + & - & + & - \\
\hline 23 & Glomus invermayanum & - & + & - & - & - & - & + & + \\
\hline 24 & Glomus leptotichum & & + & - & - & + & + & + & - \\
\hline 25 & Glomus monosporum & + & - & + & + & - & - & - & - \\
\hline 26 & Glomus mosseae & - & + & - & + & + & - & + & - \\
\hline 27 & Glomus pansihalos & + & - & + & + & + & + & + & + \\
\hline 28 & Glomus tenebrosum & + & + & + & + & + & - & + & - \\
\hline 29 & Glomus trimurales & + & + & + & - & + & - & + & - \\
\hline 30 & Scutellospora arenicola & - & - & + & + & - & + & - & + \\
\hline 31 & Scutellospora auriglobosa & - & - & - & - & + & - & + & - \\
\hline 32 & Scutellospora calospora & + & + & + & + & + & + & + & + \\
\hline 33 & Scutellospora dipapillosa & + & - & - & - & + & - & - & + \\
\hline 34 & Scutellospora dipurpurascens & + & + & + & - & - & - & - & + \\
\hline 35 & Scutellospora fulgida & + & + & + & - & - & + & - & + \\
\hline
\end{tabular}




\begin{tabular}{|l|l|c|c|c|c|c|c|c|c|}
36 & Scutellospora gregaria & - & - & - & - & - & - & + & - \\
\hline 37 & Scutellospora heterogama & + & + & + & + & - & - & - & + \\
\hline 38 & Scutellospora minuta & + & + & + & + & + & + & + & + \\
\hline 39 & Scuellospora pellucida & + & + & + & + & + & + & + & + \\
40 & Scutellospora persica & + & - & + & + & - & - & - & - \\
\hline 41 & Scuellospora weresubiae & + & - & + & - & + & - & - & + \\
\hline
\end{tabular}

(S5), Kusur (S6), Gawandgaon (S7) and Mukhed (S8)

\section{LITERATURE CITED}

1 Al-Karaki GN, Al-Raddad A (1997) Effects of arbuscular mycorrhizal fungi and drought stress on growth and nutrient uptake of two wheat genotypes differing in drought resistance. Mycorrhiza 7:83-88.

2 Al-Karaki GN (1998) Benefit, cost and water-use efficiency of arbuscular mycorrhizal durum wheat grown under drought stress. Mycorrhiza 8:41-45.

3 Azcon-Aquilar, R. and Barea, J. M. 1982. Compartive effects of foliar or soil- applied nitrate on vesicular- arbuscular mycorrhizal infection in maize. New Phytologist. 92: 553-559

4 Bagyaraja, D. J. and Sreeramulu, K. R. 1982. Pre-inoculation with VA mycorrhiza improves growth and yield of chilli transplanted in the field saves phosphatic fertilizer. Plant Soil. 69: 375-381.

5 Barea, J. M., Azcon, R. and Azcon- Aguilar, C. 2002. Mycorrhizosphere interactions to improve plant fitness and soil quality. Antonie Van Leewenhock. pp. 343-351

6 Brundrett, M. C. 2002. Coevolution of roots and mycorrhizas of land plants. New Phytologist. 154: 275-30.

7 Faber BA, Zasoski RJ, Burau RG, Uriu K (1990) Zinc uptake by corn as affected by vesicular-arbuscular mycorrhizae. Plant Soil 129:121-130

8 Feng G; Zhang FS; Li XL; Tian CY; Tang CX; Rengel Z. 2002. Uptake of nitrogen from indigenous soil pool by cotton plant inoculated with arbuscular mycorrhizal fungi. Communications In Soil Science And Plant Analysis. 33(19-20):3825-3836.

9 Garg, N. and Chandel, S. 2010. Arbuscular mycorrhizal networks: Process and functions. A review. Agron. Sustain. Dev. Volume 30, July-September 2010.

10 Gerdemann, J. W. and J. M. Trappe 1974. The Endogonaceae in the Pacific Northwest.Mycologia Mem. 5: 1-76.

11 Gerdemann, J.W. and Nicolson, T.H. (1963). Spore of mycorrhizal Endogone species extracted from soil by wet sieving and decanting. Trans. Br. Mycol. Soc.46: 235-244.

12 Hall, I. R. and Abbott, L. K. 1984. Some Endogonaceae from South Western Australia. Trans. Brit. Mycol. Soc. 82: 30. 
13 Hulugalle, NR; Nehl, DB; Weaver, TB. 2004. Soil properties, and cotton growth, yield and fibre quality in three cotton-based cropping systems. Soil \& Tillage Research. 75(2):131-141.

14 Jackson M.L.1973 Soil chemical analysis, New Delhi, Prentice Hall.

15 McGee, PA; Torrisi, V; Pattinson, GS. 1999. The relationship between density of Glomus mosseae propagules and the initiation and spread of arbuscular mycorrhizas in cotton roots. Mycorrhiza. 9(4): 221-225.

16 Morton, J.B. \& S.P. Bentivenga. 1994. Levels of diversity in endomycorrhizal fungi (Glomales, Zygomycetes) and their role in defining taxonomic and non taxonomic groups. Plant and Soil 159: 47-59.

17 Mosse, B. 1981. Vesicular-arbuscular mycorrhiza research for Tropical Agriculture. Hawai: Hawai Institute of Tropical Agriculture and Human Resources, University of Hawaii. 82 pp. [Research Bulletin 194]

18 Myrold, D.D. 2000. Microorganisms. pp. 409. In: D.E. Alexander \& R.W. Fairbridge (eds.) Encyclopedia of Environmental Science. Kluwer Academic Publishers, The Netherlands.

19 Nehl DB; Allen SJ; Brown JF. 1996. Mycorrhizal colonisation, root browning and soil properties associated with a growth disorder of cotton in Australia. Plant and Soil. 179(2):171-182.

20 Nehl, DB; Allen, SJ; Brown, JF. 1998. Slow arbuscular mycorrhizal colonisation of fieldgrown cotton caused by environmental conditions in the soil. Mycorrhiza. 8(3):159-167.

21 Ojala, J. C., Marrell, W., Menge, J. A., Johnson, E. L. V. and Platt, R. G. 1983. Influence of mycorrhizal fungi on the mineral nutrition and yield of onion in saline soil. Agron. J. 72: 255259.

22 Patale, S. W. 2016. Screening of Brinjal Rhizosphere Soil for Assessment of AM Fungi. Int. Jour. of Adv. Multi. Res. 3(1): 74- 77.

23 Patale, S. W. and B. P. Shinde 2010a. Studies on Tomato (Lycopersicon esculentum Mill) with reference to AM fungi. ASIAN J. EXP. BIOL. SCI. SPL: 6-14

24 Patale, S. W. and B. P. Shinde 2010b. Occurrence of Arbuscular Mycorrhizal Fungi from Rhizosphere and Non-rhizosphere Soil of Lycopersicon esculentum Mill. FLORA AND FAUNA Spl. 17:20.

25 Patale, S. W. and B. P. Shinde 2012a. Effect of salinity stress on growth performance of BtCotton inoculated with AM fungi. Ad. Plant Sci. 25 (1): 135- 139.

26 Patale, S. W. and B. P. Shinde 2012b. Effect of water stress on growth performance of BtCotton inoculated with AM fungi. Ad. Plant Sci. 25 (1): 127- 134.

27 Patale, S. W. and B. P. Shinde 2012c. Influence of Glomus species and soil phophorous on Verticillium wilt in Bt Cotton. J. Adv. Lab. Res. III (IV): 307- 312. 
28 Pattinson GS, Warton DI, Misman R, McGee PA. 1997. The fungicides Terrazole and Terraclor and the nematicide Fenamiphos have little effect on root colonisation by Glomus mosseae and growth of cotton seedlings. Mycorrhiza 7(3): 155-159.

29 Perry, D.A., M.P. Amaranthus, J.G. Borchers, S.L. Borchers \& R.E. Brainerd. 1989. Bootstrapping in ecosystems. Bioscience 39: 230-237.

30 Phillips J.M. and D.S.Hayman, (1970). Improved procedures for clearing roots and staing parasitic and vesicular arbuscular mycorrhizal fungi for rapid assessment of infection. Transaction British Mycological Soc. 55(I): 158-160.

31 Reddy, B. N., Hindumathi, A. and Raghavender, C. R. 2006. Influence of physico-chemical factors on arbuscular mycorrhizal population associated with sorghum. Indian J of Bot. Res. 2: 75-82.

32 Reddy, B. N., Hindumathi, A. and Raghavender, C. R. 2007. Occurrence and systematic of arbuscular mycorrhizal fungi associated with sorghum. J of Phytological Res. 20: 11-22.

33 Schenck and Perez 1990: Manual for the identification of V A Mycorrhizal fungi 3rd edition.

34 Schenk, N.C. 1981. Can mycorrhizae control root diseases. Plant Disease 65: 230-234

35 Schussler A., Schwartzzott D. \& Walker C. (2001). A new phylum, the Glomeromycota: phylogeny and evolution. Mycological Research 105: 1413-1421.

36 Simon, L. 1996. Phylogeny of the Glomales: Deciphering the past to understand the present. New Phytologist 133: 95-101.

37 Smith, S.E. and Read, D.J. 1997. Mycorrhizal symbiosis. Second Edition. Academic Press, London, UK.

38 Sreeramulu, K. R. and Bagyaraj, D. J.1986. Field response of chilli to VA mycorrhiza on black clay soil. Plant and Soil. 93: 299-302.

39 Suresh, V. V. 2000. Effect of nitrogen and potassium on yield and quality parameters of byadagi chilli (Capsicum annum L). M.Sc (Agri), Thesis, Uni. Agri. Sci., Dharwad.

40 Sylvia DM, Hammond LC, Bennett JM, Haas JH, Linda SB (1993) Field response of maize to a VAM fungus and water management. Agron J 85:193-198

41 Taylor, T.N. 1990. Fungal associations in terrestrial paleoecosystems. Trends in Ecology and Evolution 5: 21-25.

42 Williams, S. E., Wollum, A. G. and Aldon,E. F. 1974. Growth of Atriplex canescens (pursh) nutt. improved by formation of vesicular arbuscular mycorrhizae. Soil Science Society of America Proceedings. 38: 962-965.

43 Zak, JC; McMichael, B; Dhillion, S; Friese, C. (1998) Arbuscular-mycorrhizal colonization dynamics of cotton (Gossypium hirsutum L.) growing under several production systems on the Southern High Plains, Texas. Agric. Ecosyst. Environ. 68: 245-254. 